\title{
LOWER CRETACEOUS UNCONFORMITY TRUNCATING EVAPORITE-CARBONATE SEQUENCE, ARARIPE BASIN, NORTHEASTERN BRAZIL
}

\author{
MARIA AUGUSTA MARTINS DA SILVA*
}

\begin{abstract}
The Lower Cretaceous (Aptian-Albian) sedimentary rocks of the Araripe Plateau, not theast interior of Brazil, are truncated by a regional unconformity. This erosional unconformity, observed during field work and later recognized in cores, is here described for the first time. This erosion gave rise to partial dissolution of the evaporitic rocks (gypsum and anhydrite) of the Araripina Formation, originating a karst topography. Following this episode of karst formation, a calcrete layer developed. The calcrete is composed of calcareous and siliceous laminar crusts capping algal shales. The presence of associated karst and calcrete registers a climatic fluctuation between wet and dry periods in the basin.
\end{abstract}

\begin{abstract}
RESUMO As rochas sedimentares do Cretáceo Inferior (Aptiano-Albiano) da Chapada do Araripe, no interior do nordeste do Brasil, são truncadas por uma discordância regional. Esta discordância erosional, observada no campo e reconhecida em testemunhos, é descrita pela primeira vez neste trabalho. A erosão responsável pela formação desta discordância dissolveu parcialmente as rochas evaporíticas (gipsita e anidrita) da Formação Araripina, originando uma topografia karst. Após esse episódio de formação de karst, houve o desenvolvimento de uma camada de calcrete composta de crostas laminares cálcarias e sillicosas, que se sobrepõem a folhelhos ricos em algas. A presença de uma topografia karst associada a uma camada de calcrete registra uma flutuação climática na bacia passando de um período úmido para um período seco.
\end{abstract}

INTRODUCTION The Araripe Basin, located in northeastern Brazil, contains a 700 m-thick Mesozoic sequence that extends in an east-west elongated direction for about $200 \mathrm{~km}$. The Mesozoic sedimentary sequence has been uplifted and it now forms a conspicuous plateau (the Araripe Plateau) with altitudes ranging from 600 to $900 \mathrm{~m}$ above sea level (Fig. 1). The sequence is well known for abundant and well preserved Cretaceous fish found in concretions in shale, and for gypsum quarries.

The Lower Cretaceous evaporite-carbonate sequence (Fig. 2) was observed during field work in July 1981, to be truncated by a regional unconformity. It is the objective of this paper to report the finding of such unconformity.

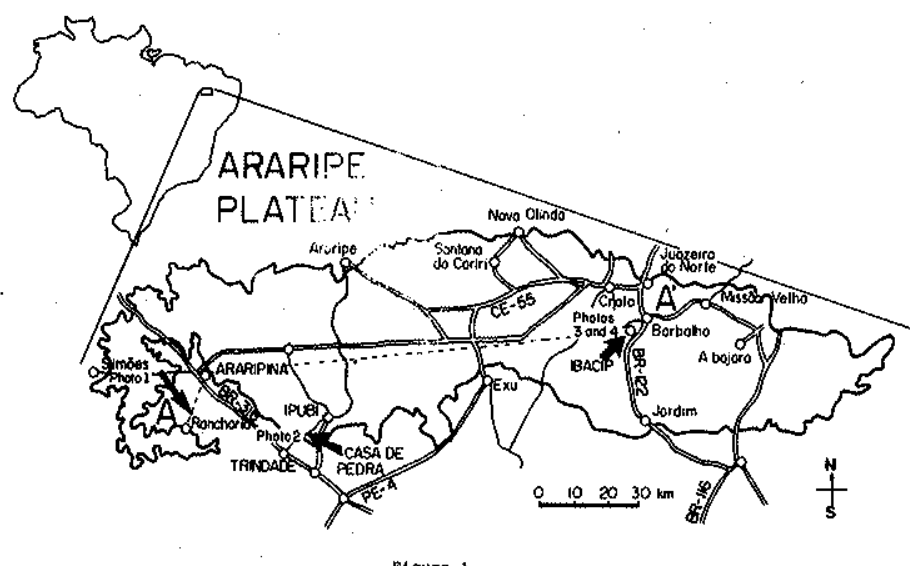

Figure 1 - Location of the Araripe Plateau in the northeastern interior of Brazil. $\mathbf{A A}^{\prime}$ line represents section shown in figure 3 (Modified from DNPM 1974)
The presence of this erosional unconformity lead to a revision of the stratigraphy which has been presented elsewhere (Silva 1983). A petrographic study of the samples collected in the field and from cores is shown in Silva (op. cit.). Here, the emphasis is on the description and interpretation of the unconformable surface, which is recognized as a karst and caliche (calcrete) paleosurface. The documentation of the events responsible for the formation of this surface has a great significance to the history of sedimentation of the area. The finding of this unconformity clarified the stratigraphic sequence of the Araripe Basin, which had been for years a matter of controversy (Beurlen 1962, 1967, 1971, Braun 1966, Lima 1979, Moraes et al. 1975, 1976, Small 1913).

GEOLOGIC SETTING The Araripe Basin contains a Jurassic-Cretaceous sequence (Fig. 2) which consists of from the bottom up: 1. basal Jurassic sandstone and shale, $300 \mathrm{~m}$-thick; 2. Aptian-Albian rocks divided into two sequences - a lower sequence of black shale, carbonate, and evaporite, and an upper sequence of calcareousconcretionary shale, limestone, and sandstone; and 3. upper layer of reddish sandstone of Albian age. The basin is surrounded by Precambrian rocks and some Paleozoic rocks to the east.

The Jurassic rocks crop out in valleys towards the east; the Aptian-Albian middle sequence (evaporite-bearing sequence) crops out along the slopes of the plateau. The whole sedimentary sequence has been gently warped, tilted, and faulted.

The Lower Cretaceous sedimentary rocks are divided into two formations bounded by unconformities: the lower Araripina Formation (new name) and the upper Santana Formation (revised) (Silva 1983, 1986). 
The Araripina Formation, which includes black shale, carbonates (limestone and dolostone), algal mats, and evaporites (gypsum and anhydrite) has been truncated by the erosional unconformity (Fig. 3). This unconformity is a major erosional surface present throughout the region.

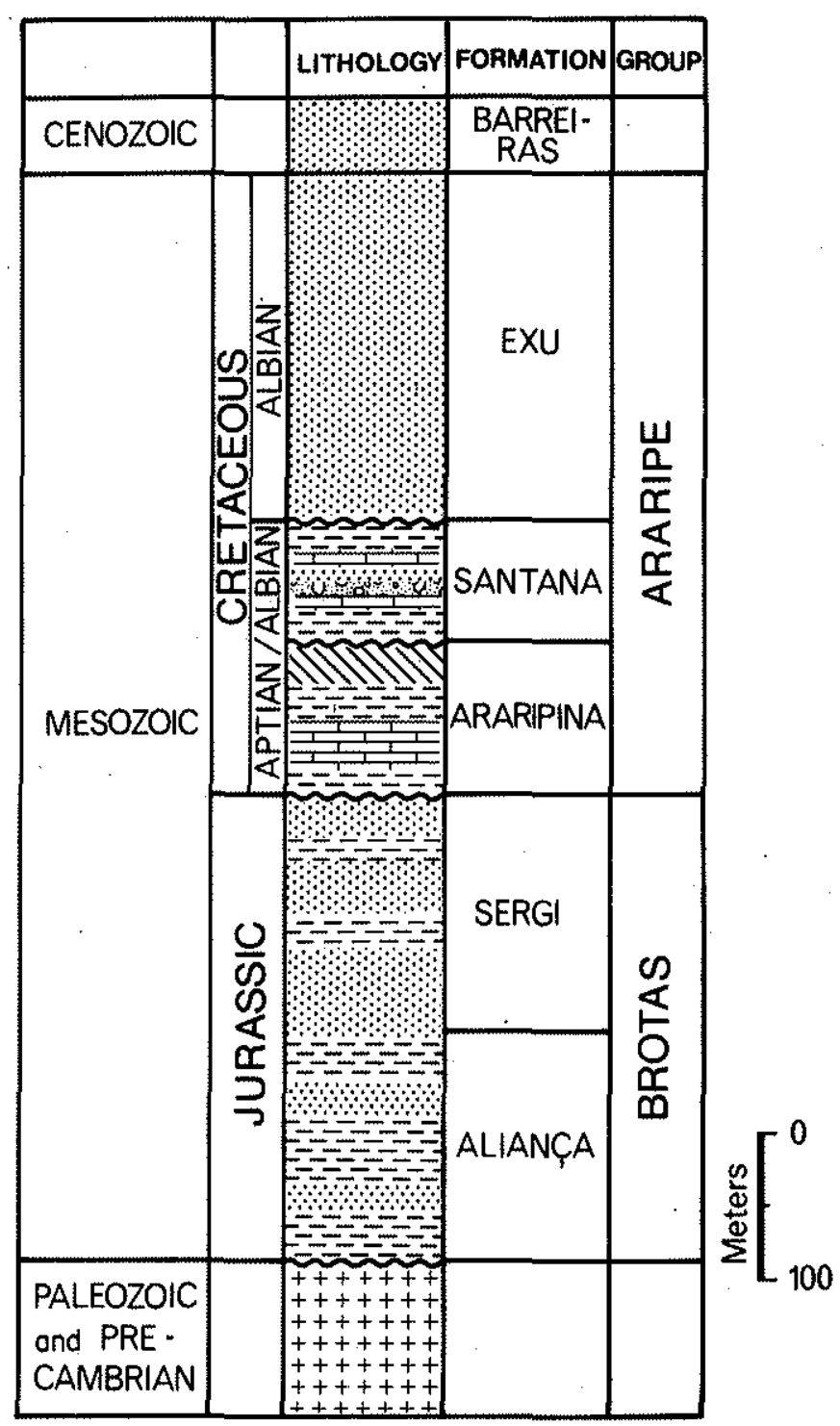

Sandstone

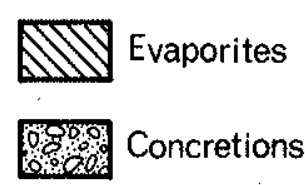

$==-$ Shate

0.890 Concretions

Carbonate

Figure 2-Columnar section and stratigraphic nomenclature for the Lower Cretaceous rocks of the Araripe Basin, as proposed by Silva (1983)

DESCRIPTION OF THE UNCONFORMITY The unconformity surface, as seen in outcrops and cores, shows different expressions across the basin. In the southwest, it appears as a paleokarst topography on gypsum bedrock (Fig. 3). Towards the northeast, it occurs mainly as a calcrete layer (Fig. 3). Each surface will be characterized below.

Paleokarst Topography The best exposures of karst are in the Rancharia-Araripina and Trindade-Ipubi areas, southwest of the basin (Fig. 1). The karst is a conspicuous feature on top of gypsum, as seen in photo 1. This photo shows an example of a solution cavity about $5 \mathrm{~m}$ deep in gypsum; the cavity has subsequently been filled by mud; some of the paleosurface cavities connect with paleosubsurface caverns (Photo 2).

Paleocalcrete Surface The calcrete layer is best recognized at IBACIP Quarry, Barbalha (Photo 3). It occurs as a $20 \mathrm{~cm}$-thick protruding hard surface overlying algal shales in the middle section of the exposure. It is composed of calcareous and siliceous laminar crusts (Photo 4). Chert occurs as nodules and milimeter-thin discontinuous laminae; drusy calcite is also observed along this surface which in places has been slightly brecciated.

Samples collected in Barbalha show, in thin section, that the calcrete is composed of a micritic sediment with chaotic fabric. Chalcedony and authigenic quartz are commonly seen either as nodules or as well-formed pyramidal, vug-filling crystals. The micrite has been brecciated by the displacive growth os fibrous calcite; calcite also fills cracks or fractures. In places, organic matter in the micrite has been expanded by the growth of calcite fibers. Watts (1978) observed this phenomenon in micas from calcrete profiles in the Scotland Permian-Triassic calcretes, which, he explains, explode to form a concertina-like structure due to displacement by the growth of displacive calcite. Another feature observed in the calcrete samples from Barbalha is the growth of displacive calcite veins with typical square ends within the micrite, such feature has been described in the Quaternary calcrete layers of the Kalahari desert (Watts op. cit.).

In cores, the calcrete interval is recognized as zones of flat pebble conglomerate, breccia (resulting from the growth of calcite and gypsum fibers), chert and chalcedony accumulations, and microspar (recrystallization), all indicative of vadose diagenesis in the former sediment.

Microcodium (Klappa 1978) and calcite needle fibers (Harrison 1977) occurring in these rocks provide additional criteria for the recognition of a caliche layer.

The paleocalcrete is a marker surface that enables the recognition of two depositional sequences in the basin. At Barbalha, overlying this surface is a $1 \mathrm{~m}$-thick conglomerate layer which marks the beginning of the upper sedimentary sequence (corresponding to the Santana Formation).

SIGNIFICANCE FOR BASIN EVOLUTION The presence of karst and calcrete has implications as to the distribution of moisture and dry conditions in the area. Karst topography is believed to imply moist conditions whereas calcrete formation is indicative of dry conditions (Wright 1980). Assuming a continuous deposition of the evaporites across the basin, then the presence of a karst topography and the local absence of evaporites, as in Barbalha, implies, respectively, partial or total removal of the evaporites during formation of karst topography. This is an indication of changing from dry to more humid conditions in the area. The calcrete layer, developed after the episode of karstification, suggests a return to less-humid conditions. 


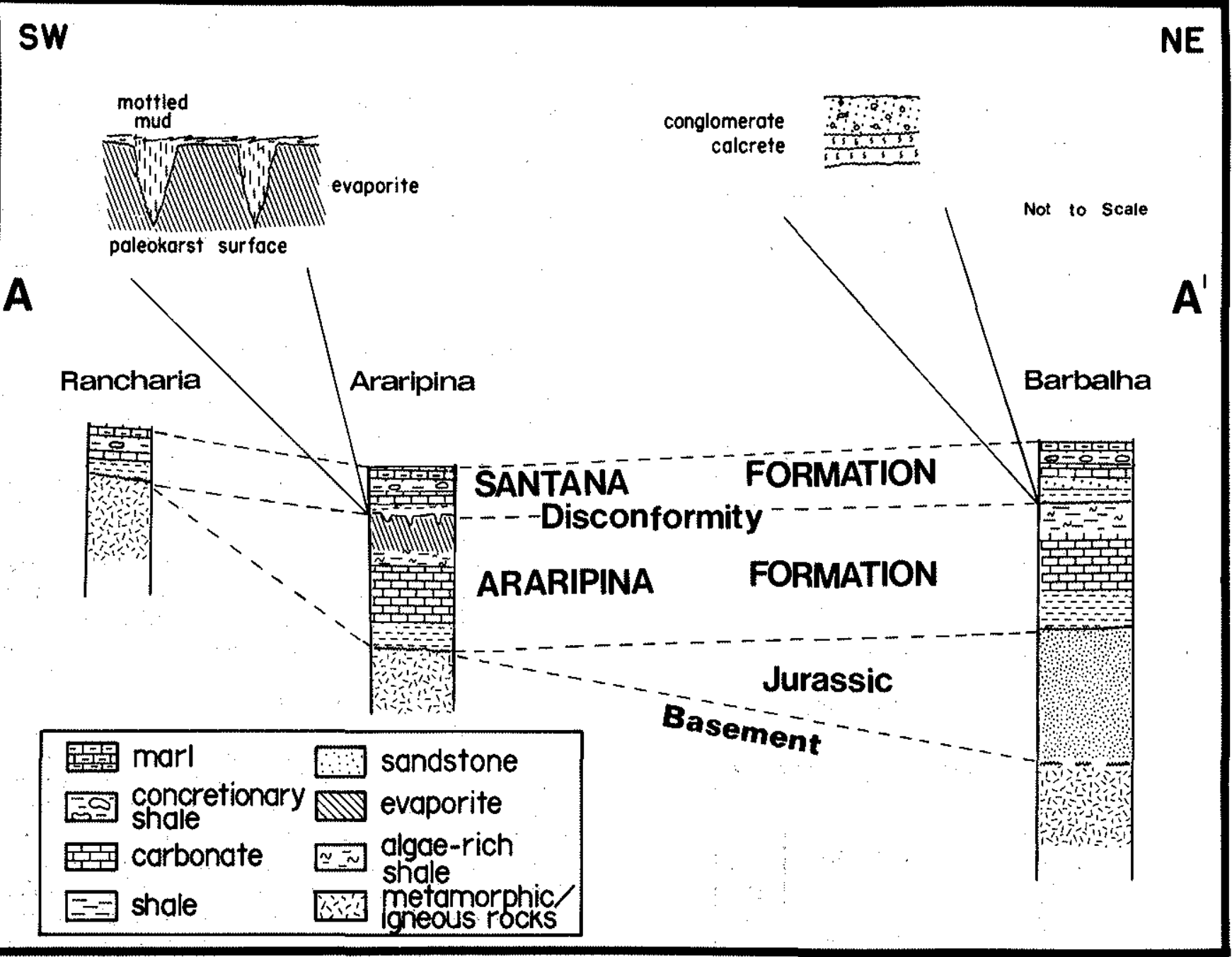

Figure 3 - Diagram illustrating the variable expression of the unconformity truncating the Araripina Formation, as seen today in the Araripe Basin (after Silva 1983)

Consequently, in this case, a climatic change from predominantly dry (evaporitic stage) to humid (karst) to dry (calcrete) occurred. The humid episode is not regarded to have been drastically different from the previous dry conditions since karstification on evaporite rocks would probably need only a slight increase in the amount of fresh water to accomplish the dissolution of sulfates. Also, the humid episode as observed in other regions of karst topography on limestone seems to last only for several thousands of years (Wright 1980, 1982). Based on the fact that the bedrock was evaporite, the interval in which the Araripe karst developed may have lasted a few thousand years.

$\mathrm{A}$ second alternative is possible, however, if we assume that the evaporites were not continuously deposited across the basin. In this case, a different picture emerges. The onset of the calcrete formation around Barbalha (where evaporites are not present) was probably contemporaneous with karstification. The implication would then be that there could have been lateral continuation between karst and calcrete which suggests that a preferential concentration of moisture existed in some regions. Similar distribution of moist and dry climates with transition from a regional karst development to a caliche soil, in lateral continuity, has been observed in Barbados (Harrison 1977). If similar conditions existed in the Araripe Basin, then no climatic change is necessary to explain the regional distribution of karst and calcrete. A local elevation of the moisture in the south would have resulted in the dissolution of the evaporites, while the rest of the basin could have been under dry conditions.

The first hypothesis seems the most likely. No evidence has been found to strongly support the assumption of a noncontinuous deposition of evaporites across the basin. Evaporites are present in nearby Barbalha-Missão Velha area indicating that local erosion most probably removed the gypsum-anhydrite layer.

CONCLUSIONS A regional unconformity truncating the Araripina Formation (Lower Cretaceous) is here described for the first time. The unconformity is observed in the field as a paleokarst and calcrete surfaces. In cores, it can be recognized as zones of flat-pebble conglomerate, breccia, and accumulation of chert and chalcedony, and recrystallization of the sediments. The presence of karst and of an overlying calcrete surface suggests a shift from 


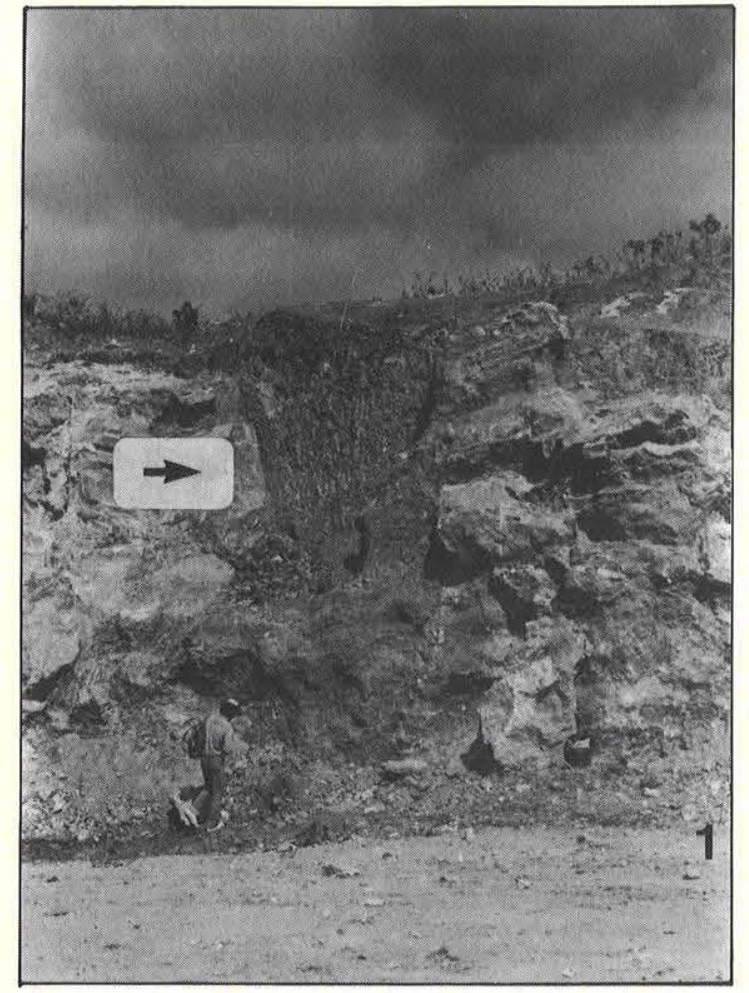

Photo 1 - Karst formed on gypsum rock, Rancharia Quarry, on road Araripina-Rancharia, southwest of Araripina. Upper sedimentary rocks have been removed by quarrying

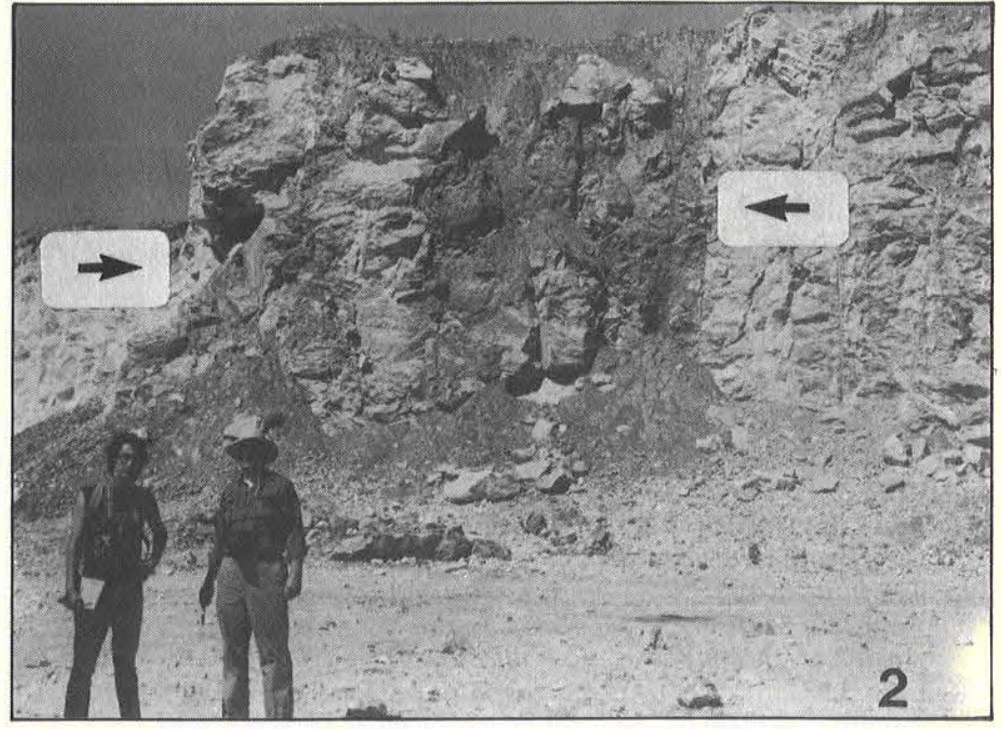

Photo 2 - Karst and interconnected cave (arrows) on gypsum rock. Ponta da Serra Quarry, road Trindade-Ipubi. Upper sedimentary rocks have been removed by quarrying

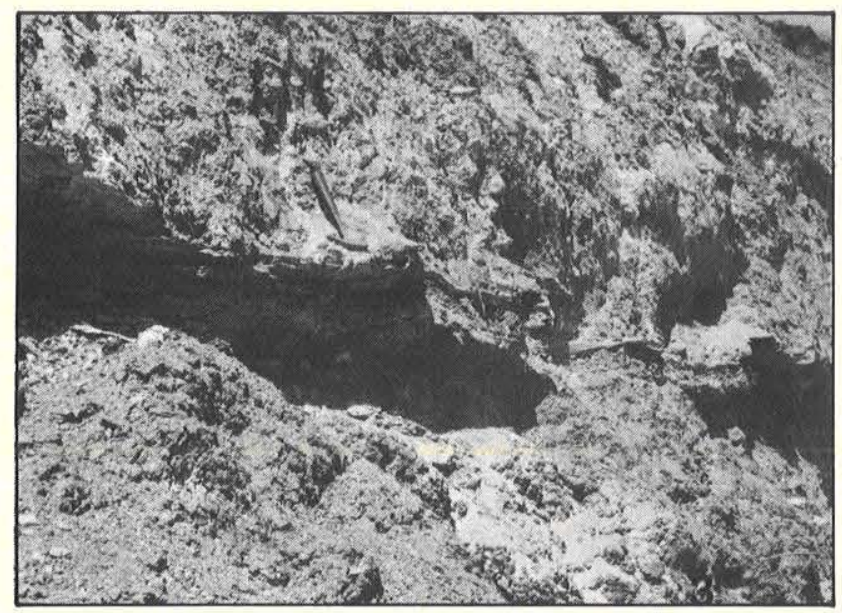

Photo 3 - Calcareous and siliceous laminar crusts of calcrete layer, protruding in the middle of exposure at IBACIP Quarry, Barbalha

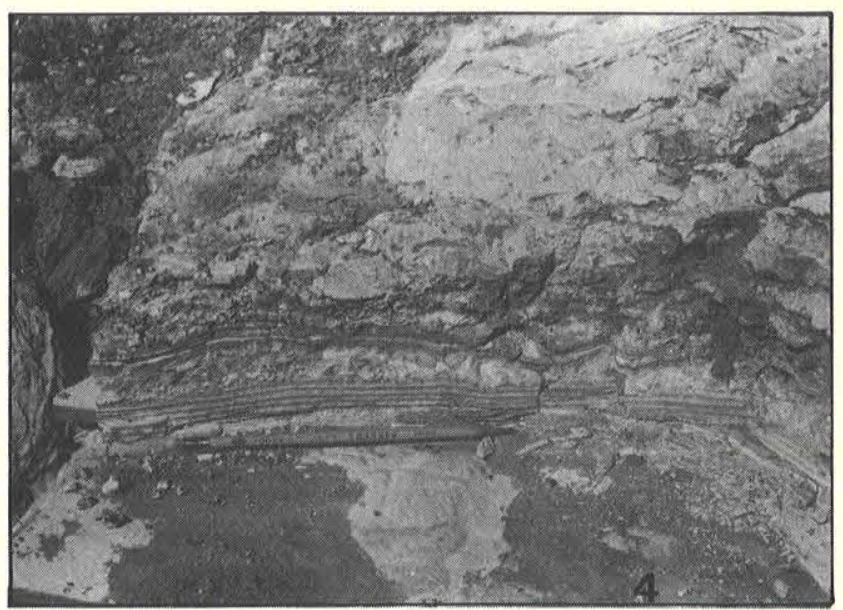

Photo 4 - Detail of calcrete layer showing milimiter-thin calcareous and siliceous laminae. IBACIP Quarry, Barbalha 
dry evaporitic conditions to a brief, more humid interval (karst) and a return to dry climate which gave rise to the calcrete layer.

Acknowledgements Financial support for this work was provided by the Conselho Nacional de Desenvolvimento Científico e Tecnológico (CNPq) (Proc 402402/80) and by Dr. John Sanders. I thank Dr. Luiz Gambôa and Dr. R. Berg of Texas A\&M University for critically reviewing the manuscript. This paper is a condensed form of one chapter of the author's Ph.D. thesis and I am grateful for the reviews of Drs. J. Sanders, R. Schweickert, J. Damuth and L. Burckle. I am grateful to Mrs. Valéria Azeredo and Neusa Maria N.Costa for typing the manuscript.

\section{REFERENCES}

BEURLEN, K. - 1962 - A Geologia da Chapada do Araripe. An. Acad. brasil. Ciênc., 34(3):365-370, Rio de Janeiro.

BEURLEN, K. - 1967 - A estrutura geológica do Nordeste do Brasil. In: CONGR. BRAS. GEOL., 21, Curitiba, 1967, Anais..., Curitiba, SBG, p. 151-158.

BEURLEN, K. - 1971 - As condições ecológicas e faciológicas da Formação Santana na Chapada do Araripe (Nordeste do Brasil). Anais Acad. brasil. Ciênc., 43 (supl.):411-415.

BRAUN, O.P.G. - 1966 - Estratigrafia dos sedimentos da parte interior da Região Nordeste do Brasil (Bacias de Tucano-Jatobá, Mirandiba e Araripe). Rio de Janeiro, DNPM/DGM, 75 p. (Boletim 235).

DNPM - Departamento Nacional da Produção Mineral - 1974 Carta Geológica do Brasil: Folha SB.24 - Jaguaribe.

HARRISON, R.S. - 1977 - Caliche profiles: Indicators of near-surface subaerial diagenesis, Barbados, West Indies. Bull. Canadian Petroleum Geology, 25(1):123-173.

KLAPPA, C.F. - 1978 - Biolithogenesis of microcodium: elucidation. Sedimentology, 25:489-522.

LIMA, H.R. de - 1979 - Considerações sobre a subdivisão estratigráfica da Formação Santana, Cretáceo do Nordeste do Brasil. Rev. Bras. Geoc., 9(2):116-121.

MORAES, J.F.S. de; SCHEID, C.; SANTOS, J. da S.A. - 1975 Projeto Santana. Relatório Preliminar da Etapa I, Recife, DNPM/CPRM, $104 \mathrm{p}$.
MORAES, J.F.S. de; SANTOS, J. da S.A.; MASCARENHAS, J. de C. - 1976 - Projeto Santana. Relatório Final da Etapa I, Recife, DNPM/CPRM, 269 p. (vol. I)

SILVA, M.A.M. da - 1983 - The Araripe Basin, Northeastern Brazil: Regional geology and facies analysis of a Lower Cretaceous evaporitic depositional complex. New York, 290 p. (PhD Thesis, Columbia University).

SILVA, M.A.M. da - 1986 - Lower Cretaceous sedimentary sequence in the Araripe Basin, Northeastern Brazil: a revision. Rev. Bras. Geoc., 16(3).

SMALL, H.L. - 1913 - Geologia e suprimento de água subterrânea no Ceará e parte do Piaui, Publicação Inspetoria Obras Contra Secas, 25 , p. 1-80.

WATTS, N.L. - 1978 - Displacive calcite: evidence from recent and ancient calcretes. Geology, 6:699-703.

WRIGHT, V.P. - 1980 - Climatic Fluctuation in the Lower Carboniferous. Naturwissenshaften, 67:252-253.

WRIGHT, V.P. - 1982 - The recognition and interpretation of paleokarsts: two examples from the Lower Carboniferous of South Wales. J. Sed. Pet., 52(1):83-94.

MANUSCRITO

Recebido em 18 de fevereiro de 1986 Revisão aceita em 18 de dezembro de 1986 